\title{
LABILITY IN ANDI
}

\author{
N. Rochant \\ Université Sorbonne Nouvelle (Paris), \\ CNRS, LaCiTO — LLACAN, Paris, France \\ neige.rochant@icloud.com
}

\begin{abstract}
This paper deals with the identification of labile verbs in Andi (Nakh-Daghestanian, Russia), and more specifically its methods, results and conclusions for the definition of transitivity in Andi. Lability is traditionally defined as an unmarked valencychanging phenomenon characterizing verbs that can be used both transitively and intransitively without any formal change. Andi happens to feature a combination of three typological characteristics that challenges not only the identification of its labile verbs, but also the application of traditional definitions of lability and transitivity to its context. These characteristics are a radical P-alignment, the absence of any agent demoting or removing morphology, and the possibility for interpreting any unexpressed agent as arbitrary. They are crucial for the analysis of labile phenomena in Andi, because they were shown by D. Creissels to be responsible for a formal ambiguity between 'less labile' passive lability (when a labile verb used intransitively has a passive meaning) and 'more labile' anticausative lability (when a labile verb used intransitively has an anticausative meaning). Several syntactic tests were designed by different authors to distinguish cases of anticausative lability from those of passive lability. These tests involve the semantic interpretation of a reflexive-emphatic pronoun, compatibility with the intransitive imperative in combination with an imperative addressee referring to the nominative argument, and the possibility of the verb being used in an involuntary agent construction. Applied to Andi, these tests show that both anticausative and passive lability concern all transitive verbs, which suggests that they do not differ with respect to their syntactic status and that both involve a change in syntactic transitivity. This conclusion supports D. Creissels's suggestion that in languages sharing with Andi the relevant typo-
\end{abstract}


logical features, transitivity applies not to the predicative constructions themselves, but to their realizations.

Keywords: lability, transitivity, valency changing derivations, alignment, ergativity, unmarked passive.

\section{Лабильность в андийском языке}

\section{Н. Рошан \\ Университет Новая Сорбонна (Париж),} Национальный центр научных исследований: Лаборатория языков и культур устной традиции / Лаборатория языков и культур Африки, Париж, Франция neige.rochant@icloud.com

Аннотация. В андийском языке выделяются три ключевых для изучения лабильности типологических характеристики: радикальный эргативный строй, отсутствие понижающих дериваций и возможность интерпретировать любой невыраженный агенс как неопределенный. Как показано Д. Кресселем, сочетание этих свойств создает омонимию между двумя семантическими типами лабильности - пассивной и антикаузативной. Различными авторами были предложены тесты, которые позволяют выявить случаи антикаузативной лабильности. По результатам этих тестов все переходные глаголы оказываются доступны и для пассивной, и для антиказаутивной лабильности; как следствие, оба типа лабильности предполагают мену переходности. Это подтверждает теорию Д. Кресселя о том, что в языках, подобных андийскому, переходность применяется не к самим предикативным конструкциям, а к их реализациям.

Ключевые слова: лабильность, переходность, актантные деривации, эргативный строй, немаркированный пассивный залог. 


\section{Introduction}

Andi is an unwritten and scarcely documented ${ }^{1}$ language belonging to the Andic branch of the Nakh-Daghestanian family. According to the 2002 Russian Federal census [Rasprostranennost vladeniya yazykami po subektam Rossiyskoy Federatsii 2002], it is now probably spoken by approximately 20,000 people, living in or resettled from nine villages of the Botlikh district of the Republic of Daghestan, Russia [Aglarov 2002: 3]. This study was conducted upon first-hand elicited data from the village of Zilo, whose dialect has been under investigation since 2016. Consequently, all examples in Andi are taken from the author's field notes ${ }^{2}$.

The current paper concerns itself with lability in the Zilo dialect of Andi, with a focus on the tests employed to detect labile verbs and how their results affect the conception of transitivity in Andi.

While section 2 lays the preliminary groundwork for the detection of labile verbs, section 3 analyses the issues that should be addressed during this process - specifically, the problematic combination of three typological features in Andi. In this respect, the analysis of Akhvakh and related languages conducted by Creissels [2014] is applied to Andi. Section 4 reviews the syntactic tests applied to Andi verbs in response to these issues. Section 5 draws conclusions on Andi transitivity from the results of the tests, which corroborate Creissels' hypothesis [Ibid.].

Lability is traditionally defined as an unmarked valency-changing phenomenon characterizing verbs that can be used both transitively and intransitively without any formal change. Andi has P-align-

${ }^{1}$ Four grammar sketches of Andi are available [Dirr 1906; Suleymanov 1957; Tsertsvadze 1965; Salimov 1968], but none of them tackles issues relevant to syntax. No Andi dictionary has ever been published so far.

${ }^{2}$ I would like to thank all my Zilo consultants (especially Aligaji G. Magomedov's family), without whom this paper could not have been written, as well as Agnes Korn for her very precious discussion and corrections. I am also very grateful to Timur Maisak for guidance in fieldwork and Andi linguistics, to Hélène Gérardin for advice on Caucasian linguistics and typology of transitivity, and to all the reviewers for helping improving this paper by their careful reading and constructive remarks. Editors of the volume and the author would like to particularly thank Sergey Say for reading and editing the first version of the paper. 
ment $^{3}$. NPs representing the S term of intransitive constructions and the $\mathrm{P}$ term of transitive constructions are in the zero-marked nominative case, whereas the A term of transitive constructions is marked by the ergative case. Besides, a substantial number of verbs contain a prefixal slot for gender-number marking, whose agreement is controlled by the nominative NP representing $\mathrm{S}$ or $\mathrm{P}^{4}$. No verb shows agreement with any other argument or in any other feature, including person. Accordingly, verbs that do not have a slot for gender-number marking do not agree with any argument.

Here are two intransitive predications, respectively with (1) and without (2) agreement in the verb:

\begin{tabular}{|c|c|}
\hline $\begin{array}{l}\text { zadizati } \\
\text { Khadizhat[F][NOM] } \\
\text { 'Khadizhat fell down'. }\end{array}$ & $\begin{array}{l}j-u k:-u \\
\text { F-fall-PST(AOR) }\end{array}$ \\
\hline ihur & $z a r \chi-u-j$ \\
\hline $\begin{array}{l}\text { lake }\left[\mathrm{INAN}_{2}\right][\mathrm{NOM}] \\
\text { 'The lake has frozen'. }\end{array}$ & freeze-PST-PF \\
\hline
\end{tabular}

Here are two transitive predications, respectively with (3) and without (4) agreement in the verb:

$$
\begin{array}{lll}
q \chi \text { 'urban-di } & \chi^{w} \text { ammi } & b-i t 5:-i-j \\
\text { Qurban-ERG } & \text { fish[AN][NOM] } & \text { AN-catch-PST-PF } \\
\text { 'Qurban caught a fish'. } &
\end{array}
$$
aliћadzi-di
refa
$q \chi u q \chi-a n$
Alihaji-ERG
$\operatorname{wood}\left[\operatorname{INAN}_{1}\right][\mathrm{NOM}]$
saw-PST(AOR)
'Alihaji sawed wood'.

${ }^{3}$ The terms "P-alignment" and "A-alignment" differ from the notions of ergativity and accusativity respectively in that they refer only to “alignment proper" [Creissels 2014: 924-925], i.e. they do not hint at any properties that "many linguists associate with [alignment] like asymmetries in marking or indexation patterns, coincidence between the quotation form of nouns and the form they show in some of their syntactic uses, presence of passive or antipassive, etc."

${ }^{4}$ There is no clear correlation between the presence of a slot for gender-number marking and any characteristics of the verb. This feature seems to be purely lexical. 
Besides transitive and intransitive constructions, Andi features a third main valency frame: the affective construction. It is used by verbs of perception ('see', 'hear', 'find', etc.), emotion ('like', 'be weary of', etc.) and cognition ('know', 'understand', 'forget', etc.). In this construction, the experiencer is marked by the dedicated affective case, while the stimulus is marked in the nominative (5). The affective marker contains a gender marker agreeing with the nominative argument, i.e. the stimulus.

$$
\begin{array}{ll}
d i-<j>o \quad \text { jofi } & \text { har-o-r-s:u } \\
\text { I.OBL-AFF }<\text { F }>\quad \text { girl[F][NOM] } & \text { see-PST-PROG-NEG } \\
\text { 'I can't see the girl'. } &
\end{array}
$$

In Andi, constituent order at clause-level is determined not by syntactic, but only by pragmatic constraints. Regarding valency changes, Andi features a causative strategy, but no valency-decreasing derivations, such as passive, anticausative or antipassive. The information structure of English passive constructions such as 'The mouse was eaten by the cat' would be rendered in Andi by the same constituents as in 'The cat ate the mouse' with special order and intonation.

Dixon [1994] introduced a distinction between agent-preserving and patient-preserving lability. In the latter, also called P-lability, "both uses of a labile verb have a patientive argument", as rephrased by Letuchiy [2009a: 265], whereas in agent-preserving lability (or Alability), "both uses preserve the agentive argument” [Ibid.]. P-lability is illustrated by (6) and A-lability by (7):

\section{P-lability - English}

(6a) I broke the car.

(6b) The car broke.

A-lability — Hinuq, Nakh-Daghestanian [Forker 2013: 492]

(7a) haze tera $=n \quad u z ̌ i-y=n o$

these.OBL five. $\mathrm{OBL}=$ and boy-ERG=and

t'ot'er-ho yasin

read-PRS sura[NOM]

'The five boys read the sura'.

(7b) $d i$

$$
u z ̌ i
$$

murad

t'ot'er-ho

I.GEN1 boy[NOM] Murad[NOM] learn-PRS




$\begin{array}{llll}\text { oc'eno } & \text { seda } & \text { klas-ma } & \text { hinuq ắ-a } \\ \text { ten } & \text { one.OBL } & \text { class-IN } & \text { Hinuq village-IN }\end{array}$

'My son Murad is studying in eleventh grade in the village of Hinuq'.

In (7a) from Hinuq (a language belonging to the Tsezic branch of the Nakh-Daghestanian family, which is closely related to the Andic languages), the verb t'ot'er- is used transitively in the meaning 'to read', with its agent NP haze tera $=n$ uži- $y=n o$ in the ergative and its patient yasin in the unmarked nominative. In (7b), the same verb is used intransitively with the meaning 'to study', the unique argument NP di uži Murad being in the unmarked nominative case.

Andi features at least three A-labile verbs: $b a i^{5}{ }^{5}$ 'TR read / INTR study', as in Hinuq, k'ari 'vomit' and urвun 'TR invent / INTR think' (8).

(8a) den urs-un mas?alal-?o

I think-PST(AOR) exercise.OBL-SUPER.LAT

'I thought about the exercise'.

$\begin{array}{llll}\text { den-ni } & \text { urs-un } & \text { he-b } & \text { mas?ala } \\ \text { I-ERG } & \text { think-PST(AOR) } & \text { DEM-INAN } & \text { exercise[INAN } \\ \text { 'I }][N O M]\end{array}$

'I invented this exercise'.

A-labile verbs are found in very limited number in Andi and thus not addressed in this study.

\section{Preliminary groundwork for the research of labile verbs in Andi}

Spotting P-labile verbs in Andi requires a first clearing-up phase destined to determine which verbs are suitable candidates for lability, based on whether they can be used both with and without an ergative argument in their underived form. As will be explained in section 3, in such a language as Andi, this is a necessary, though not sufficient criterion to characterize a verb as labile.

The material used for this first stage consists in a database of 321 verbs elicited from Russian to Andi in one basic sample sentence.

${ }^{5}$ The aorist has been chosen as the verb citation form for its minimal morphological markedness combined with maximal morphological informativity. 
For example, the Andi equivalent of Russian zasypat' 'fall asleep' was obtained by translating from Russian to Andi the sentence Xadizhat zasnula 'Khadizhat fell asleep', chosen arbitrarily ${ }^{6}$. Identifying potential candidates for lability throughout this database consists, for each token, in adding an ergative agent to the sample construction if it is intransitive $^{7}$, or removing the ergative agent from the sample construction if it is transitive, and then in checking the result's grammaticality and meaning with several consultants:

Sample construction $\mathrm{V}\left\{\mathrm{S}_{\text {NOM }}\right\}+\mathrm{A}_{E R G}={ }^{\text {OK }}$ or $*$ ?

Sample construction $\mathrm{V}\left\{\mathrm{P}_{\text {NOM }}, \mathrm{A}_{E R G}\right\}-\mathrm{A}_{E R G}={ }^{\text {OK }}$ or $*$ ?

Groups of sentences (9) and (10) provide examples of tested verbs:

$$
\begin{array}{ll}
k \text { 'epi } & r-u k \cdot-u \\
\text { jug[INAN } & \text { ][NOM] INAN } 2 \text {-fall-PST(AOR) }
\end{array}
$$

'The jug fell down'.

(9b) *pat'imati-di k'epi $r-u k:-u$

Patimat.OBL-ERG jug[ INAN $\left._{2}\right][\mathrm{NOM}]$ INAN $_{2}$-fall-PST(AOR)

\#‘ Patimat dropped the jug'.

$$
{ }^{o K} \text { pat'imati-di k'epi r-uk:-ot-i }
$$

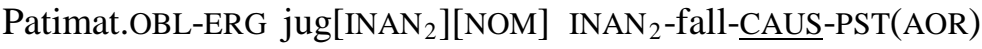
'Patimat dropped the jug'.

${ }^{6}$ This database was established as a preparatory basis for further studies. The construction in which a verb is stored in the database must not be considered the basic or main construction of this verb, as it is the translation of a sentence chosen arbitrarily, whose construction is dependent on the morphosyntactic profile of the source language and can influence the choice of the construction in the target language. However, the arbitrary character of the constructions stored in this database is not a problem for the use made of them in the present study.

${ }^{7}$ The opposition between intransitive and transitive is to be understood here within the notion of 'syntactic transitivity', as distinguished by Letuchiy [2010: 250] from that of valency. The definition of intransitivity under the paradigm of syntactic transitivity includes "intransitive verbs that are not monovalent, if neither of their arguments is a direct object” [Ibid.]. 
The verb CL-uk: $u$ 'fall' is stored in the database in the sample intransitive construction of example (9a). As shown by (9b-c), adding an ergative NP to this construction is licensed only for the causativized verb, and not for the simple verb. The verb CL-uk: $u$ is hence excluded from the group of potentially labile verbs. So are all verbs using the affective construction (experiencer verbs), which never include an ergative argument in their underived form.

(10a) derzik'a

$b-e z-a$

pumpkin[INAN $\left.{ }_{1}\right][\mathrm{NOM}] \quad$ INAN $_{1}$-brown-PST(AOR)

'The pumpkin browned'.

(10b) ${ }^{\text {oK }}$ den-ni derzik'a $b-e z-a$

I-ERG pumpkin[INAN 1 [NOM] INAN $_{1}$-brown-PST(AOR)

'I cooked (lit.: browned) the pumpkin'.

The verb CL-eza 'brown' is stored in the database in the sample intransitive construction of example (10a). As shown by (10b), the same verb can combine with an ergative NP without undergoing causativization. The verb CL-eza is retained as potentially labile.

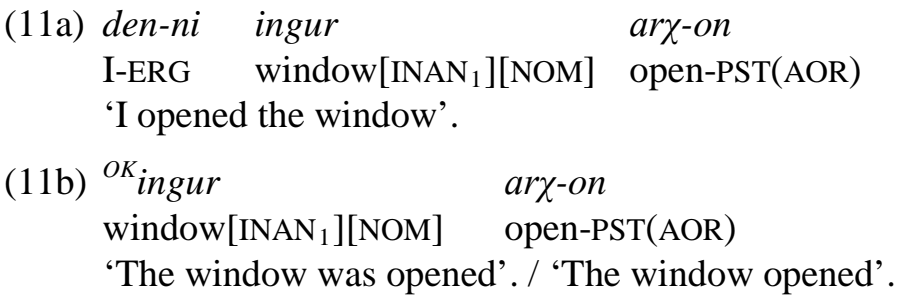

The verb aryon 'open' is stored in the database with the sample transitive construction in (11a). Example (11b) shows that its ergative NP can be removed without the sentence becoming ungrammatical. The verb aryon is retained as potentially labile.

Two observations can be made from the results: first, there is an imbalance between verbs elicited in an intransitive sample construction and verbs elicited in a transitive sample construction. Among the former group, very few are compatible with an ergative argument in their underived form, whereas all tokens of the latter group prove to be grammatical with their ergative argument removed. Although this imbalance cannot be considered significant at this stage, since the construction in which verbs in the database were elicited is arbitrary 
(many of them could as well have been elicited from a sentence with the opposite construction), it is worth mentioning as it correlates with the results of this study (which can probably be explained by the verb semantic features that partly guided the choice of the source constructions for elicitation).

Sample construction $\mathrm{V}\left\{\mathrm{S}_{\mathrm{NOM}}\right\}+\mathrm{A}_{E R G}=*$ in the vast majority of cases.

Sample construction $\mathrm{V}\left\{\mathrm{P}_{\text {NOM }}, \mathrm{A}_{E R G}\right\}-\mathrm{A}_{E R G}={ }^{\mathrm{OK}}$ in all cases.

Secondly, the meaning of constructions with the ergative argument removed is often ambiguous between a passive and an anticausative reading, as illustrated in (11b).

Section 3 is intended to shed light on these two observations.

\section{Detecting labile verbs in Andi: Theoretical and practical issues}

The method described in section 2 is not sufficient for identifying labile verbs in Andi. It allows to sift out verbs which are undoubtedly not labile - those that cannot combine with an ergative argument in their underived form. However, verbs that are filtered in during the procedure cannot be diagnosed as labile with an equal reliability.

Indeed, Andi displays typological features that are involved in theoretical discussions about the definition of lability and issues for identifying labile verbs. These points and their relation to the typological characteristics at stake have been raised and analyzed by Creissels [2014] using material from four other Nakh-Daghestanian languages, especially from Akhvakh, a language closely related to Andi, as it belongs to the same Andic group.

The typological features that have to be taken into account when studying lability according to Creissels are radical P-alignment, the absence of agent demoting or removing morphology, and the possibility for the agent of any construction to be left unexpressed with an arbitrary (i.e. unspecified) reading.

\subsection{Radical P-alignment}

According to the definition given by Creissels [2014: 926], a language is said to have a "radical alignment" if its transitive and intransitive constructions present no other formal distinction than the presence vs. absence of a (specific) second NP, as illustrated by (12)- 
(13). In the case of radical A-alignment, this NP is the P term, whereas with radical P-alignment, this NP is the A term.

$$
\begin{array}{ll}
\text { het } \int \text { ink'a } & r \text {-iz-un } \\
\text { corn[INAN } 2][\mathrm{NOM}] & \text { INAN }_{2} \text {-grow-PST(AOR) }
\end{array}
$$

'The corn has grown'.

$$
\begin{array}{lll}
q \chi \text { 'urban-di } & \chi u r & r \text {-ett'-o } \\
\text { Qurban-ERG } & \text { field[INAN } 2][\mathrm{NOM}] & \text { INAN }_{2} \text {-plow-HAB }
\end{array}
$$

'Qurban plows the field'.

In (13), the only hint that the construction is transitive is the presence of the ergative NP Q ' 'urbandi. No other feature distinguishes it from the intransitive construction in (12). Transitivity is encoded neither by any markers, neither in cross-reference, since ergative NPs are never encoded in the verb in Andi. The only argument that might be encoded in the verb is the nominative one (which is always present regardless of the transitivity of the construction).

In languages that do not have radical alignment, intransitive and transitive constructions are straightforwardly distinct, e.g. because both the $\mathrm{A}$ and $\mathrm{P}$ terms are encoded in the verb thanks to cross-referencing affixes, as in Adyghe (14)-(15), or through the use of special markers, as in Mandinka (16)-(17).

ADYGHE [Arkadev et al. 2009: 61]

(14a) se $s-e-k^{w} e$

I 1SG.ABS-DYN-go

'I am walking (lit.: I go)'.

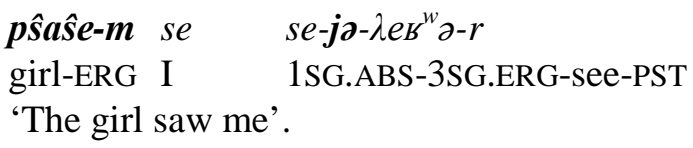

In Adyghe, which has P-alignment, both $\mathrm{A}$ and $\mathrm{S} / \mathrm{P}$ terms are encoded in the verb by the means of cross-referencing prefixes: in the intransitive construction (14a), the $S$ term is encoded in the verb $k^{w} e$ 'go' through the prefix s-; while in the transitive construction (14b), the $\mathrm{P}$ term se ' $\mathrm{I}$ ' is encoded in the verb $\lambda \boldsymbol{s}^{\mathrm{w}} \mathrm{z}$ ' 'see' through the prefix se(an allomorph of $s-$ ), and the A term psisem 'girl' through the prefix je-. Consequently, (15a) and (15b) differ not only in the absence vs. presence of an ergative NP, but also in the absence vs. presence of 
a cross-referencing prefix encoding the ergative argument in the predicate. Since Adyghe has non-radical alignment, P-lability is considered "strong" in the framework of Creissels [2014]. Strong lability, which is a strictly formal feature, is a consequence of non-radical alignment and means that the intransitive and transitive uses of a labile verb are distinguished not only by the mere presence vs. absence of a NP, but also by other means. In Adyghe, the intransitive and transitive uses of a P-labile verb are distinguished not only by the presence vs. absence of an A term, but also by the encoding of the A term in the verb of the transitive construction. For example, the transitive use of the verb waș $\hat{s}^{w}$ eja 'stain' in (15b) is distinct from its intransitive use in (15a) thanks to the encoding of the A term through the prefix sə-.

ADYGHE [Letuchiy 2009b: 415]

(15a) žane-r woṣ $\hat{S}^{w} e j \partial-r$

shirt-ABS stain-PST

'The shirt got stained'.

(15b) se s-jə-ð̌ane-r

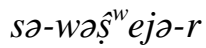

I 1SG.PR-POSS-shirt-ABS 1SG.ERG-Stain-PST

'I stained my shirt'.

In Mandinka, transitive and intransitive constructions are distinguished by markers encoding both TAM and transitivity. In (16a), the marker tá suffixed to the verb jaa 'be / become dry' indicates that the construction is in the completive positive tense and is intransitive. In (16b), the marker ye, placed between the A term kambaan-óo 'boy' and the P term saâ 'snake', indicates that the construction is in the completive positive tense and is transitive. Consequently, (16a) and (16b) differ not only in the absence vs. presence of an NP, but also in their TAM-transitivity markers.

MANDINKA [Creissels 2015: 2]

(16a) dendik-óo jaa-tá

shirt-DEF

til-óo be/become_dry-CMP.POS.INTR

sun-DEF la

'The shirt dried up in the sun'.

(16b) kambaan-óo boy-DEF ye

CMP.POS.TR sãa

snake.DEF 


$\begin{array}{lll}\text { búsá } & \text { fál-óo } & \text { la } \\ \text { hit } & \text { stick-DEF } & \text { OBL }\end{array}$

'The boy hit the snake with a stick'.

Because Mandinka has a non-radical alignment, lability in this language qualifies as strong lability. For example, the intransitive and transitive uses of the labile verb faa 'kill / die' in (17) are distinguished thanks to the aforementioned markers.

MANDINKA [Creissels 2014: 915]
(17a) saajíy-o
faa-ta
sheep-DEF
kill/die-PF.POS.INTR
'The sheep died'.

\begin{tabular}{lll} 
(17b) kew-ó ye & \multicolumn{1}{c}{ saajíy-o } & faa \\
man-DEF PF.POS.TR & sheep-DEF & kill \\
'The man killed the sheep'. &
\end{tabular}

The examples of Adyghe and Mandinka show how non-radical alignment results in strong lability. Conversely, the consequence of radical P-alignment is that "P-lability can only be of the weak type" [Creissels 2014: 932] ${ }^{8}$. Weak lability is the opposite of strong lability - it means that the two uses of labile verbs are not distinguished other than by the presence vs. absence of a (specific) second noun phrase. As illustrated by example (18), again from Andi, the only difference between the two uses (18a) and (18b) is the presence of the ergative NP denni in the first one.
(18a) den-ni derzik'a
$b-e z-a$
I-ERG pumpkin[INAN $\left.{ }_{1}\right][\mathrm{NOM}]$ INAN $_{1}$-brown-PST(AOR)
'I cooked the pumpkin'.

(18b) derzik'a

$$
b-e z-a
$$

pumpkin[INAN $\left.{ }_{1}\right][\mathrm{NOM}] \quad$ INAN $_{1}$-brown-PST(AOR)

'The pumpkin has cooked'.

What is of particular importance for this paper is that, as a consequence of radical P-alignment, a transitive construction with an unexpressed A term will be formally indistinct from an intransitive con-

${ }^{8}$ Radical A-alignment affects A-lability in the same way as radical P-alignment affects P-lability. 
struction, whereas its argument structure is still \{agent, patient . As put by Creissels [2014: 929], "there is no possibility to distinguish patients encoded as the $\mathrm{P}$ term of a transitive construction with a missing agent from patients encoded as the $S$ term of an intransitive construction".

As shown in $(18 a)=(19 a)$, the verb CL-eza 'brown' allows the transitive construction. If one removes the ergative NP from this construction, the resulting predication has two possible readings, $(18 b)=(19 b)$ and (19c). As transitive and intransitive predications are not distinguishable other than by the presence vs. absence of an A term, (19b) and (19c) may be formally identical, but could differ in syntactic transitivity: (19b) could be intransitive, with its nominative argument derzik'a encoded as the S term, and (19c) a transitive predication with a missing agent, with its nominative argument derzik'a encoded as the P term. As will be shown in section 3.2, this ambiguity affects all labile verbs.

(19a) den-ni derzik'a $b-e z-a$

I-ERG pumpkin[INAN 1$]$ [NOM] INAN $_{1}$-brown-PST(AOR)

'I cooked the pumpkin'.

(19b) derzik'a $b-e z-a$

pumpkin[ INAN $\left._{1}\right][\mathrm{NOM}] \quad$ INAN $_{1}$-brown-PST(AOR)

'The pumpkin has cooked'.

$$
\text { derzik’a }
$$

$b-e z-a$

$\mathrm{A}_{\varnothing} \quad$ pumpkin[INAN 1 [NOM] INAN $_{1}$-brown-PST(AOR)

'The pumpkin was cooked (lit. Ø cooked the pumpkin)'.

\subsection{Unrestricted use of null A's for the expression of arbitrary} agents

As mentioned in section 1 , Andi has no agent demoting or removing morphology, i.e. no passive or anticausative derivation. Arbitrary agents, expressed in English through passive constructions such as 'The mouse was eaten', are rendered in Andi by the mere non-realization of the A term (cf. (20)). The agent of any construction can be left unrealized to be read as arbitrary.
(20a) den-ni jo/i
qхamm-i
I-ERG girl[F][NOM]
capture-PST(AOR)
'I captured the girl'. 
(20b) $\varnothing$

$$
\text { joji }
$$

qхamm-i

$\mathrm{A}_{\varnothing}$

$\operatorname{girl}[\mathrm{F}][\mathrm{NOM}]$

capture-PST(AOR)

'The girl was captured'.

The verb qxammi 'capture' allows the transitive construction, as illustrated by (20a). The same construction with its A term unrealized in (20b) yields the reading of a passive with an arbitrary (or unspecified) agent.

All Andi verbs used with the transitive construction are subject to this phenomenon, which is called "lability of the passive type", or "argument structure preserving P-lability” by Creissels [2014]. This kind of lability does not involve any reassignment of the semantic roles: while a patient is present both formally and semantically in both its uses, an agent is formally absent from one of the uses, but always semantically present.

3.3. Argument structure preserving and argument structure modifying P-lability

Argument-structure preserving P-lability is opposed to what Creissels [2014] called argument structure modifying P-lability, or "lability of the anticausative type", which involves a reassignment of the semantic roles between the two uses of a labile verb and corresponds to constructions of the (19b) type. Indeed, in the latter, the agent of one of the uses is not only formally, but also semantically absent from the second. Example (21) provides another illustration of argument structure modifying P-lability, as (21a) has an agent (denni) and a patient (s:urati), while (21b) involves one single autonomous participant kempeti (in the prism of syntactic transitivity as defined by Letuchiy [2010: 250], cf. footnote 7).

den-ni s:urati $\quad b$-ats'-i
I-ERG picture[INAN 1 [NOM] INAN INtick-PST(AOR) $_{1}$ 'I glued the picture's pieces together (lit.: I stuck the
picture)'. \{agent, patient

pat'imati-?a

kempeti

Patimat.OBL-SUPER[ESS]

candy[ $\left.\mathrm{INAN}_{1}\right][\mathrm{NOM}]$ 
$b$-ats'-i-j

INAN $_{1}$-stick-PST-PF

'A candy has stuck to Patimat'. \{one single autonomous participant\}

In the absence of a morphosyntactic distinction between intransitive constructions on the one hand and transitive constructions with an unrealized agent on the other hand, the syntactic status of P-lability, including argument structure preserving P-lability, is unclear. In a predication with an unrealized agent read as arbitrary, there is no possibility to determine if it is intransitive, with a semantic patient encoded as an $\mathrm{S}$ term, or transitive, with a semantic patient encoded as a $\mathrm{P}$ term ${ }^{9}$.

As noted by Creissels [2014: 923], in order to solve this question, one has to determine at which level syntactic transitivity operates in a given language. Only if transitivity is found to apply not to the predicative constructions themselves, but to their realizations, can the Andi alternations of the type denni jo/i qxammi 'I captured the girl' / jo/i qxammi 'The girl was captured' be considered labile, because it would imply defining a syntactically transitive construction as a construction in which both $\mathrm{A}$ and $\mathrm{P}$ are overtly expressed. This question might be a mere matter of interpretation, but it could also be elucidated through syntactic tests.

Nevertheless, this issue is not exactly at stake here, for argument structure preserving lability is of secondary interest against argument structure modifying lability. Indeed, the former is negative to the second criterion for lability stated by Letuchiy [2009a] — a change of semantic roles. The latter type, though, does involve a change of semantic roles, as it consists in an alternation \{agent, patient\} / \{one autonomous participant $\}$ of the causative/inchoative type as defined by Haspelmath [1993a].

In a context where verbs allowing the transitive construction are all subject to lability of the passive type, cases of anticausative lability are always ambiguous with passive lability. However, it does not mean

${ }^{9}$ As suggested by Creissels [2014: 923], this uncertainty mirrors the dubiously A-labile alternations such as 'Mary eats the apple' / 'Mary eats', in languages with radical A-alignment. Indeed, as mentioned in section 3.1, radical A-alignment results in A-lability being weak. 
that cases of passive lability are always ambiguous with anticausative lability: one has to consider the theoretical existence of verbs lending themselves only to lability of the passive type. Consequently, our goal is to find verbs allowing for anticausative lability (i.e. alongside passive lability), checking them for an alternation in syntactic transitivity. If the syntactic status of passive lability is unclear, attesting an alternation in syntactic transitivity for cases of anticausative lability requires addressing them systematically by means of specific tests. Such lability tests are designed to find if a verb manifestly allowing for the transitive construction allows for the intransitive construction as well. Applied to null-A constructions, these tests are intended to:

1. Clearly separate cases of anticausative lability from those of passive lability by removing the ambiguity between them, which is necessary to explicitly distinguish verbs allowing for both. However, only finding verbs that allow exclusively passive lability can provide the most convincing evidence of an efficient disambiguation.

2. Find which Andi verbs allowing for the transitive construction also lend themselves to null-A constructions with an anticausative reading - as explicitly distinguished from passive readings.

3. Elucidate if anticausative uses of null-A constructions are syntactically intransitive - implying a correlation between the semantic absence of an agent in the described situation and the syntactic absence of an A-term in the construction.

\section{The application of lability tests}

Four lability tests have been suggested in the literature. They were designed by authors dealing with Nakh-Daghestanian languages in which the detection of labile verbs is rendered difficult by the possibility to omit any argument retrievable from the context, or by other relevant typological features that they share with Andi.

\subsection{The reflexive-emphatic pronoun test}

The first test, adapted from [Kibrik 1996: 111], who used it for Godoberi, and from [Lyutikova 2001: 380], who applied it to Bagvalal (both of which belong to the Andic branch of the Nakh-Daghestanian family), consists in analyzing the possible readings of the reflexiveemphatic pronoun. Similarly to those languages, Andi displays a pro- 
noun $3 i-C L=g u$, whose possible interpretations depend on the syntactic transitivity of the construction.

If the construction is intransitive, the pronoun is interpreted as reflexive, and the clause has a meaning like: ' $\mathrm{S}$ does $\mathrm{V}$ by itself'. This case is illustrated by (22). If the construction is transitive, then P does not exercise control, which makes the reflexive reading unavailable; thus, the pronoun can only have an emphatic use, and the construction means 'A affects $P$ itself', 'It is $P$ that A affects', 'A affects $P$ and nothing else' (23), where the type of affection is denoted by the verb.

$$
\begin{aligned}
& \text { zi-r } r=g u \quad r-i z-u n \\
& \text { RFL-INAN }_{2}=\text { EMPH } \quad \text { INAN }_{2} \text {-grow-PST(AOR) } \\
& \text { q } \chi^{\prime} \text { urtfi-tti refa } \\
& \text { apricot-GEN tree[ } \left.\text { INAN }_{2}\right][\mathrm{NOM}]
\end{aligned}
$$

'The apricot tree grew by itself (i.e. without human participation)'.

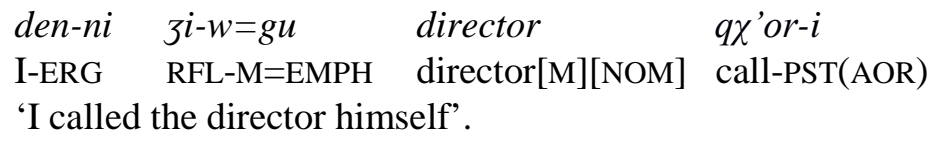

This test is used to emphasize the semantic difference between passive and anticausative uses of null-A constructions so as to help distinct them clearly. This distinction is a requirement for identifying if a verb used with an empty agent slot allows for both anticausative and passive readings, or only for the passive one. However, only if this test allows to find verbs that sanction exclusively passive lability - and not for any semantic reasons - does it show that the passive and anticausative uses are indeed syntactically distinct. If a verb used in a null-A construction cannot yield an anticausative meaning, but only a passive one, this restriction should be made clear by pronoun $3 i-C L=g u$ lending itself only to the emphatic reading, illustrated by examples (24)-(26):$$
3 i-w=g u
$$
director
qX'or-i
$\mathrm{A}_{\varnothing} \quad \mathrm{RFL}-\mathrm{M}=\mathrm{EMPH}$ director[M][NOM] call-PST(AOR)
'The director himself was called'.

(25) $\varnothing$

$$
\begin{aligned}
& \text { petfenijol } \quad 3 i-b-u l=g u \\
& \text { cookie[INAN } \left._{1}\right] . P L[N O M] \text { RFL-INAN } \\
& \text {-PL }=E M P H
\end{aligned}
$$


quur-u-mado

crumble-PST-PROG

'It is the cookies that are being crumbled (lit.: The cookies themselves are being crumbled)'.

$\varnothing \quad t / a j \quad 3 i-b=g u \quad t s$ 'ad-i-r

$\mathrm{A}_{\varnothing}$ tea[ $\left[\mathrm{INAN}_{1}\right][\mathrm{NOM}]$ RFL-INAN ${ }_{1}=\mathrm{EMPH}$ drink-PST-PROG

'Tea is drunk without anything else in it (lit.: Tea itself is drunk)'.

We expect from a labile verb to allow for both reflexive (as in (22)) and emphatic (as in (24)-(26)) readings of the pronoun. This test is applied to verbs lending themselves to the transitive construction to check which ones allow for the reflexive reading of the pronoun zi$\mathrm{CL}=g u$ in absence of a realized agent. Consequently, $z i-C L=g u$ is placed before or after the only overt argument of the tested verb. Here are a few examples of tested verbs:

\begin{tabular}{|c|c|}
\hline ingur & $z^{i}-b=g u$ \\
\hline $\begin{array}{l}\text { window[INAN } 1][\mathrm{NOM}] \\
\text { PST(AOR) }\end{array}$ & RFL-INAN $_{1}=\mathrm{EMPH}$ \\
\hline
\end{tabular}

'The window opened by itself'.

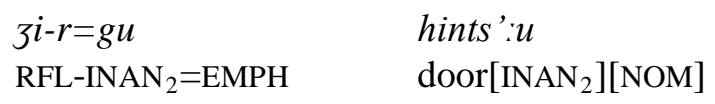

$r$-oqX'-on

INAN $_{2}$-close-PST(AOR)

'The door closed by itself'.

As a result, all verbs whose semantics allow for a spontaneous event reading in absence of an expressed agent, such as 'close' or 'open' (something can close or open by itself without the participation of an agent) can easily combine with the reflexive reading of pronoun $3 i-C L=g u$, see (27) and (28). This is not the case for verbs whose semantics do not allow for a spontaneous event reading, as illustrated by (29).
(29) $t / a j$
$3 i-b=g u$
ts'ad-i-r
tea[INAN $\left.{ }_{1}\right][\mathrm{NOM}]$ RFL-INAN ${ }_{1}=\mathrm{EMPH}$
drink-PST-PROG
?'Tea drinks by itself'.
${ }^{\mathrm{OK}}$ 'It is tea that is drunk'. 
In construction (29), proposed to a consultant without context, the pronoun $3 i-C L=g u$ cannot receive but an emphatic reading. However, setting a fantastic or fairy-tale-like context during elicitation enables the reflexive reading of $3 i-C L=g u$ even with verbs that are a priori semantically incompatible with anticausative lability. Indeed, this kind of context, in which objects that are normally inanimate can exceptionally be endowed with life or free motion ability, allows to override unfitness for a spontaneous event interpretation. Illustration is provided by (30) and (31):

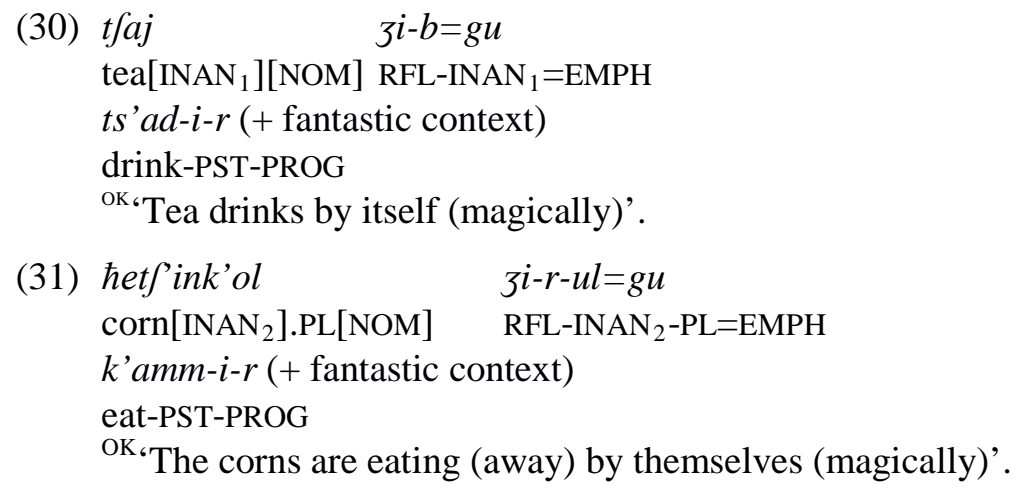

An alternative to the fantastic context is to set what I call a 'sarcastic negative context', where a sentence says that this or that is not going to be done by itself, in order to urge the hearer to get to work. This strategy is illustrated in (32) and (33).

(32) refa

$$
\begin{aligned}
& 3 i-b=g u \\
& \text { RFL-INAN } 1-P L=E M P H
\end{aligned}
$$

wood[INAN $\left.{ }_{1}\right][\mathrm{NOM}]$

kann-es:a!

hew-FUT.NEG

'The wood isn’t going to hew itself (lit.: to hew by itself)!'

(33) gaga $3 i-r=g u$

seed[INAN 2$][\mathrm{NOM}]$

RFL-INAN 2 -PL $=E M P H$

r-ett'-es:a!

INAN $_{2}$-plant-FUT.NEG

'The seeds aren't going to plant themselves (lit.: to plant by themselves)!' 
All the primary verbs submitted to this test are found to allow for the reflexive reading of the pronoun $3 i-C L=g u$, sometimes conditionally upon the setting of fantastic or sarcastic negative contexts. Table 1 provides a summary of the results. However, since the reflexive-emphatic pronoun test does not allow to find any verb unfit for anticausative lability, it does not help syntactically distinguish anticausative from passive lability, nor does it explicitly show that cases of anticausative lability are syntactically intransitive - as it is a semantic test.

Table 1 . Verbs tested positive to lability with the reflexive-emphatic pronoun test

\begin{tabular}{|c|c|c|}
\hline $\begin{array}{l}\text { Positive in any } \\
\text { context }\end{array}$ & $\begin{array}{l}\text { Positive in fantastic } \\
\text { context }\end{array}$ & $\begin{array}{l}\text { Positive in sarcastic negative } \\
\text { context }\end{array}$ \\
\hline 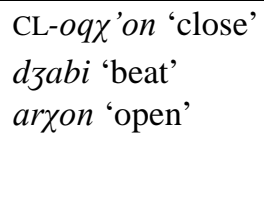 & 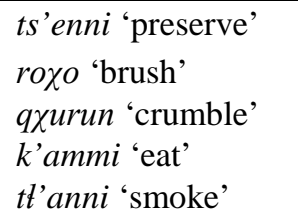 & 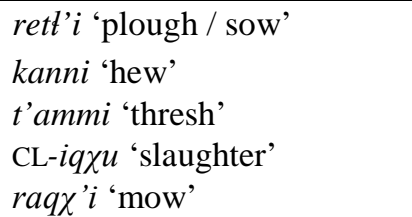 \\
\hline
\end{tabular}

\subsection{The imperative test}

The second test, likewise found in [Kibrik 1996: 110] and [Lyutikova 2001: 379], consists in checking which imperative forms a verb is compatible with. As in closely related Godoberi and Bagvalal, the Andi imperative is the only form of the paradigm that is marked for transitivity: Andi features two different imperative forms, one of which is used in intransitive constructions, the other in transitive ones. As shown in (34), the imperative in $/-b /$ (realized $[m]$ in case of a nasal stem) suffixed to the past stem of the verb is used in intransitive constructions:

$$
\begin{array}{ll}
j \text {-er } s-a-b & h o<j>a ! \\
\text { F-hurry-PST-IMP(INTR) } & \text { here }<\mathrm{F}> \\
\text { 'Come here quickly!' } &
\end{array}
$$

As illustrated by (35), the imperative in /-o/ suffixed to the athematic stem ${ }^{10}$ of the verb is used in transitive constructions:

${ }^{10}$ The athematic stem, as opposed to the past and non-past stems, does not involve any vocalic suffix. It consists in the bare verb stem (which is always consonant-final). 
(35) hints':u

door[ $\left[\mathrm{INAN}_{2}\right][\mathrm{NOM}]$

'Lock the door!' $r-\mathrm{i} / d-o$ !

INAN $_{2}$-lock-IMP(TR)

Verbs that sanction only the intransitive construction cannot form an imperative of the transitive type. We expect from a labile verb to be able to form both imperatives. Hence, the imperative test consists in checking if a verb lending itself to the transitive construction - and thus compatible with the transitive imperative - can form an intransitive imperative as well. As a result, all the primary verbs submitted to this test are found to be able to form an intransitive imperative.

Example (36) shows that the verb CL-ak'arun 'gather', which allows the transitive construction in (36a), is compatible with the intransitive imperative in (36b).

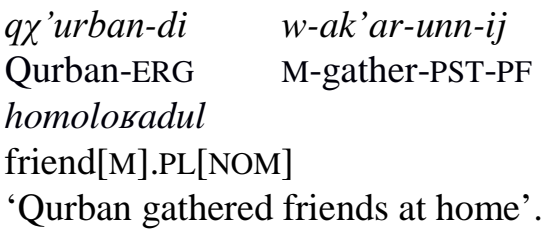

(36b) w-ak'ar-u-m-ul,

homoloвadul!

M-gather-PST-IMP(ITR)-PL

friend[M].PL[NOM]

'Friends, gather yourselves!'

Examples (37) and (38) show that the verbs arzon 'open' and $q \chi$ 'abfon 'blink' respectively are compatible with both transitive (a) and intransitive (b) imperative markers. As in most cases, the use of the intransitive imperative requires the setting of a fantastic context (cf. (37b) and (38b)).

(37a) $a r \chi-o n$

hints':u!

open-IMP(TR) door[INAN 2$][\mathrm{NOM}]$

'Open the door!'

(37b) hints:'u,

door[INAN $\left.{ }_{2}\right][\mathrm{NOM}]$

*ar $\chi$-o-m! / ${ }^{\text {OK }}$ ar $\chi$-o-m! (+ fantastic context)

open-PST-IMP(ITR)

'Door, open yourself!' 
(38a) $q \chi$ 'abf-on

hark'obil!

blink-PST-IMP(TR) eye[INAN 1 ].PL[NOM]

'Blink eyes!'

(38b) hark'obil,

eye[INAN 1 ].PL[NOM]

${ }^{*} q \chi^{\prime} a b f-u-m-u l ! ~ / ~{ }^{O K} q \chi^{\prime} a b f-u-m-u l !$ (+ fantastic context)

blink-PST-IMP(ITR)-PL

'Eyes, blink!'

Positivity to the imperative test can be considered as evidence for compatibility with the intransitive construction. The following test is used in combination with the imperative test to add to the evidence.

\subsection{The imperative addressee test}

The third test was used in [Forker 2013: 493-494] for Hinuq. Its purpose is to corroborate the results of the imperative test. It lies in the assumption morphological selection of the imperative form should correlate with an overt syntactic feature: selection of the argument in the role of imperative addressee. Intransitive imperative constructions select their unique argument as imperative addressee, whereas transitive imperative constructions only allow for the ergative argument as imperative addressee.

What makes Andi all the more sensitive to this test is that the imperative addressee can be overtly expressed not only outside the imperative clause in function of vocative (which takes the unmarked form, as the nominative case), but also within the clause as subject of the imperative predicate. As for any other subject, the imperative subject is inflected for case, which makes apparent if it is an intransitive or a transitive subject. Example (39) features a transitive construction where the imperative addressee expressed as vocative NP pat'imat is also overtly expressed as imperative subject NP in the ergative case menni ${ }^{11}$.
pat'imat,
men-ni
b-ed:-o
Pat'imat[F]
thou-ERG
INAN $_{1}$-leave-IMP(TR)

${ }^{11}$ It is noteworthy that an inflected imperative subject cannot be used as a vocative. 
vedra!

bucket[ INAN $\left._{1}\right][\mathrm{NOM}]$

'Patimat, leave the bucket!'

Example (40) features an intransitive construction where the imperative addressee is overtly expressed as vocative NP wofo and imperative subject NP in the nominative case men.

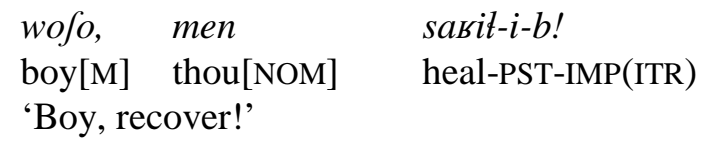

If a verb can form an intransitive imperative, it should also be able to select the nominative argument of the construction as imperative addressee, which can be identified by its overt expression in functions of both vocative and imperative subject inflected for case. The test is applied to verbs allowing for the transitive construction in combination with the test of the imperative form. As a result, all submitted primary verbs test positive to lability. For example, under the condition of a fantastic context, the verbs CL-ifdi 'lock' (41), $b^{w} a n q \chi$ 'un 'drown' (42) and dzabi 'beat' (43), which are all compatible with the transitive construction (cf. (41a), (42a) and (43a)), can form an intransitive imperative and select their nominative argument as imperative addressee, here visible in the form men.

(41a) pat'ma, hints':u r-i/d-o!

Patma[F] door INAN $_{2}$-lock-IMP(TR)

'Patma, lock the door!'

(40b) hints':u, men

door[INAN $\left.{ }_{2}\right]$ thou[NOM]

$r-i \int d-i-b !(+$ fantastic context)

INAN $_{2}$-lock-PST-IMP(ITR)

'Door, lock yourself!'

(42a) hindi-w

$$
b^{w} \text { anqX'-on! }
$$

DEM-M[NOM] drown-IMP(TR)

'Drown him!'

(42b) gama,

men

boat[INAN ${ }_{1}$ thou[NOM] 
$\boldsymbol{B}^{w} a n q \chi^{\prime}-u-m !(+$ fantastic context)

drown-PST-IMP(ITR)

'Boat, drown!'

(43a) pozarnif-di

zarzal

d3ab-i

fireman.OBL-ERG bell[INAN $\left.{ }_{1}\right][\mathrm{NOM}]$

'The fireman rang the bell'.

(43b) zarzal,

bell[INAN $\left.{ }_{1}\right]$

'Bell, toll!' men $\quad d z a b-i-b(+$ fantastic context)

thou[NOM] beat-PST-IMP(ITR)

The verbs that test positive to both morphological and syntactic imperative tests joined together are dzabi 'beat', $q \chi$ 'abfun 'blink', ruto

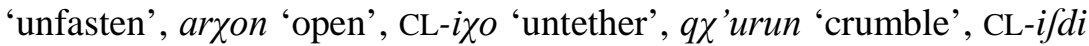
'lock', CL-ak'arun 'gather', $b^{w}$ anq $\chi$ 'un 'sink', obi 'touch', CL-ats'i 'stick', and ts'enni 'preserve'. The two imperative-related tests combined bring up consistent results in favor of all primary verbs being compatible with the intransitive construction, which is distinguished from the transitive one by the morphology of the imperative mood.

\subsection{Test of the involuntary agent construction}

The last test was used in [Haspelmath 1993: 291-293] for Lezgi, a Nakh-Daghestanian language remotely related to Andi. Similarly to Lezgi, Andi displays a bivalent construction in which the agent, marked by a spatial case, performs an action by accident, typically because of a wrong movement. When modified by a converb meaning 'unknowingly', the semantics of the construction is extended to involuntary events not involving physical accidents. The involuntary agent is marked by the contelative case ${ }^{12}$, dedicated to the expression of a movement from a position of contact. The specificity relevant to the present matter is that this construction is syntactically intransitive. Indeed, it is allowed by all verbs lending themselves exclusively to the intransitive construction, if the latter are semantically compatible with it. However, it is not allowed with verbs that are overtly marked for transitivity, i.e. causativized verbs.

${ }^{12}$ The contelative case is marked by a combination of two suffixes: the contlocative case marker $-t /{ }^{\prime} u$, and the elative marker $-k: u$. 
(44a) piq $i$

$z a r \chi-u-j$

fruit[INAN $\left.{ }_{1}\right][\mathrm{NOM}] \quad$ freeze-PST-PF

'The fruits have frozen'.

(44b)

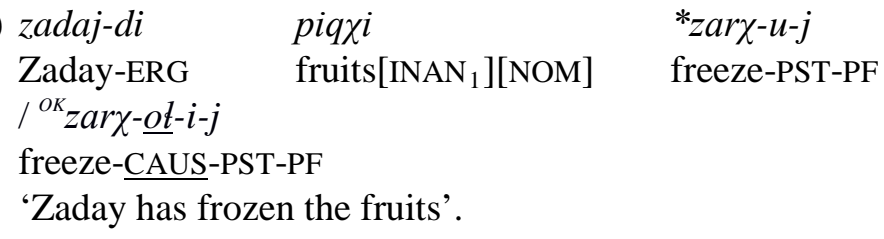

(44c) di-t/'u-k:u ts'inn-i-t/'igu

I.OBL-CONT-EL know-PST-CVB.NEG

piq $i$

zar $\chi-u$

fruit[INAN $\left.{ }_{1}\right][\mathrm{NOM}] \quad$ freeze-PST(AOR)

/ *ar $\chi$-ot-i

freeze-CAUS-PST(AOR)

'I have involuntarily let the fruits freeze'.

(44d) ${ }^{\text {OK }}$ den-ni ts'inn-i-t/'igu

I-ERG know-PST-CVB.NEG

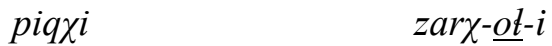

fruit[INAN $\left.{ }_{1}\right][\mathrm{NOM}] \quad$ freeze-CAUS-PST-PF

'I have involuntarily let the fruits freeze'.

The verb zar $\chi u$ 'freeze' uses the intransitive construction (44a) and cannot use the transitive one without undergoing causativization (44b). The involuntary agent construction is possible with the primary form of the verb zar $\chi$, but not with its causativized form zar $\chi$-ot-i (44c). The latter requires the agent to be marked in the ergative (44d) ${ }^{13}$.

The involuntary agent construction is thus expected to be allowed only by verbs lending themselves to the intransitive construction, which can be used as a lability test if applied to verbs already identified as compatible with the transitive construction. As expected, all tested primary verbs are suitable for the involuntary agent construction if their semantics allows for a spontaneous event

${ }^{13}$ As opposed to the involuntary agent construction, the transitive construction is unmarked for the agent voluntariness, i.e. it does not exclude that the action is performed involuntarily, and can also combine with the converb meaning 'unknowingly'. 
reading, i.e. if it does not require strong agentivity properties from the agent. Examples (45)-(47) are illustrations of verbs that test positive:

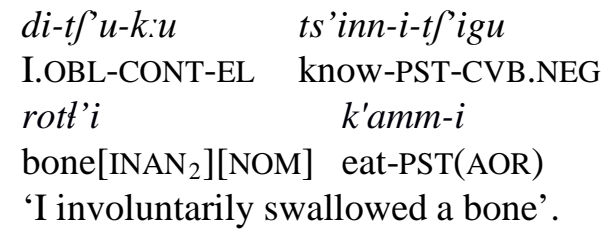

(46)
$\operatorname{di-t} \int^{\prime} u-k: u$
ts'inn-i-t八'igu
I.OBL-CONT-EL knOw-PST-CVB.NEG
famm-i san
throw-PST(AOR) bread[INAN 1$][\mathrm{NOM}]$
'I involuntarily threw away the bread'.

(47) hedef-tfu-k:u ts'inn-i-t/'igu

DEM.OBL.M-CONT-EL know-PST-CVB.NEG

dzab-i gedu

beat-PST(AOR) cat[AN][NOM]

'He involuntarily killed (lit.: beat) a cat'.

The results are summarized in Table 2, which shows that the verbs that test negative are those whose semantics do not meet the aforementioned requirement, in that their agent must be strongly agentive.

Table 2. Results of the involuntary agent construction test

\begin{tabular}{|c|c|c|}
\hline \multicolumn{2}{|c|}{ Verbs tested positive } & Verbs tested negative \\
\hline fammi ‘throw’ & CL-ifdi 'lock' & ts'enni 'preserve' \\
\hline CL-aұo 'end up' & arzon 'open' & itf:i 'give' \\
\hline dzabi 'kill’ & funni 'smell' & 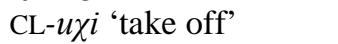 \\
\hline k'ammi 'eat' & CL-uqX'i 'cut' & tt'anni ‘pull’' \\
\hline $\begin{array}{l}\text { CL-eza 'fry' } \\
\text { q qurun 'crumble' }\end{array}$ & CL-oq $\chi$ 'on 'close' & $\begin{array}{l}\text { CL-ufo 'paint' } \\
\text { CL-ed:o 'leave' }\end{array}$ \\
\hline
\end{tabular}

\subsection{Results of the lability tests}

The four lability tests produce consistent and straightforward results: all primary verbs allowing the transitive construction also lend themselves to the intransitive construction.

The only verbs that test negative to all four tests are derived verbs containing either a causative or a factitive marker. For deriving 
verbs from adjectives or adverbs, Andi features two suffixes in equipollent distribution ${ }^{14}$ : the factitive suffix /-jd/, which means 'to render something $X$ ', and the inchoative ${ }^{15}$ suffix $/-t /$, which means 'to become $X^{\prime}$, in both cases of which $X$ is the property denoted by the stem. Applied to the same verb, these two suffixes describe the same process with the exception that factitive /-jd/ implies the necessary presence of a semantic agent in the argument structure, whereas inchoative /- $t /$ does not "hint at the causality chain" [Creissels 2014: 935] of the event, expressing spontaneous changes of state. The causative suffix in /-ol/ (realized [-ot] before the vowel $i$ ), which derives verbs from other verbs, encodes the presence of a semantic agent in the same manner as the factitive suffix. Both factitive and causative suffixes have a correlate that does not imply the action of an agent: the form derived through by the inchoative suffix and the primary form of the verb respectively. Therefore, in absence of a semantic agent in the argument structure, it is not surprising that the more neutral form is selected against that which is overtly marked for the presence of an agent.

Examples (48) and (49) illustrate the incompatibility of the intransitive construction with the factitive marker and with the causative marker respectively.

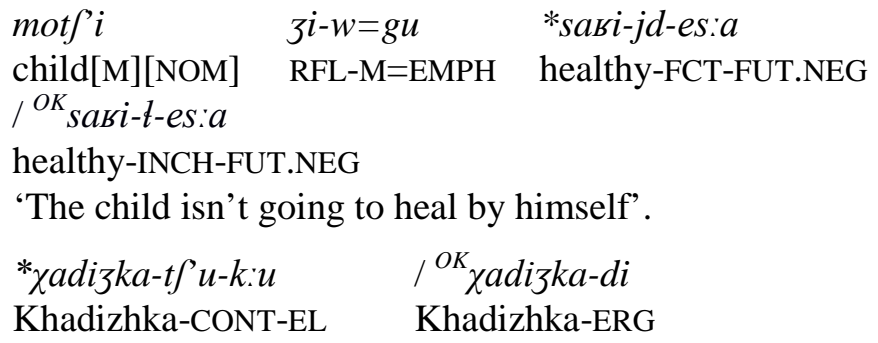

${ }^{14}$ Haspelmath [1987: 4] called "equipollent” an alternation in which "both alternants are symmetrical, i.e. in most cases both are marked, e.g. by means of root affixes".

${ }^{15}$ In [Haspelmath 1993b: 90], "an inchoative verb meaning” is opposed to a "causative verb meaning" in that "it excludes a causing agent and presents the situation as occurring spontaneously". In that sense, the equipollent factitive / inchoative pair of derivational suffixes is an alternation of the causative / inchoative type. 


$\begin{array}{ll}\text { ts'inn-i-t/'igu } & \text { igru/ka } \\ \text { know-PST-CVB.NEG } & \left.\text { toy[INAN }{ }_{1}\right][\mathrm{NOM}] \\ b-u k \text {-ot-i } & \\ \text { INAN }_{1} \text {-fall-CAUS-PST(AOR) } \\ \text { 'Khadizhka involuntarily dropped a toy'. }\end{array}$

One can evaluate the lability tests according to the objectives mentioned in section 3.3. The reflexive-emphatic pronoun test helps to semantically disambiguate anticausative and passive uses of null-A constructions, but does not allow to clarify the syntactic status of anticausative lability - i.e. to show that it implies a change in syntactic transitivity. As for the three other tests, they show that anticausative uses of null-A constructions are indeed intransitive, and hence that anticausative lability does imply a change in syntactic transitivity. However, none of these tests evince any syntactic difference between passive and anticausative lability. Indeed, only the existence of verbs that allow exclusively for passive lability would prove that the syntactic status of the latter is different from that of anticausative lability. The tests show that all verbs which use the transitive construction lend themselves to anticausative lability. Semantic incompatibility with lability, i.e. unfitness for a spontaneous event interpretation, proves not to be a constraint on syntactic lability, as it can be overridden during elicitation by setting a particular context, fantastic or other, in the application of the reflexive-emphatic pronoun or the imperative tests. Consequently, the reflexive-emphatic pronoun test enables a semantic disambiguation, but no test allows for a syntactic distinction. Therefore, objective 1 - disambiguation between passive and anticausative uses of null-A constructions - is met only partially. As to objectives 2 and 3 - identifying verbs that allow anticausative lability and checking the latter for a change in syntactic transitivity, - they are fulfilled by the three last tests.

None of the tests used above allow to distinguish a syntactic class of labile verbs. They all seem to be semantic tests rather than syntactic. This is not surprising, given that, according to Letuchiy [2013: 44], hardly any tests ever reveal a syntactic class of labile verbs in typology: lability tests usually distinguish uses of verbs rather than lexemes, which is why lability can be likened to a semantic derivation. 


\section{Conclusions on transitivity in Andi}

Having in mind that all primary verbs using the transitive construction are P-labile provides a better understanding of how Andi primary verbs differ in their transitivity properties. As noted by Creissels [2014: 934] regarding Akhvakh "and other languages that share the relevant typological features", the traditional contrast "intransitive" vs. "transitive” verbs is substituted in Andi by a distinction between "[verbs] that [can] combine with an ergative NP in their nonderived form, and [verbs] with which the presence of an ergative NP representing an agent must be licensed by causative derivation". The former group of verbs could be defined as "transitive" only in the sense that strict transitivity does not exist in Andi, whereas the latter group can qualify as "strictly intransitive".

The four lability tests substantiate the view that anticausative lability is as pervasive as passive lability in Andi, since both types are shown to apply to all members of the same class of verbs. It confirms Creissels's analysis, according to which whatever results were described in the grammars of Godoberi and Bagvalal, "the tests in question do not really make apparent syntactic distinctions between the transitive verbs that can be used intransitively with an anticausative meaning and the other transitive verbs" [Creissels 2014: 932]. Indeed, according to Lyutikova [2001: 378] and Kibrik [1996: $110]$, the tests make it possible to delineate a rather restricted class of labile verbs; however, it seems that the verbs that are excluded as nonlabile are either causative verbs or primary verbs semantically incompatible with a spontaneous event reading. The systematic application of the same tests to Andi verbs previously identified as using the transitive construction, including those semantically incompatible with lability, makes it possible to draw a different map.

This procedure does not reveal any syntactic difference between argument structure preserving lability and argument structure modifying lability, which supports Creissels's view that "the distinction between [them] is of rather semantic than syntactic nature, all transitive verbs being syntactically weakly labile” [Creissels 2014: 932].

If, in Andi, anticausative lability is syntactically equivalent to passive lability, the question remains whether this syntactically homogeneous lability does involve an alternation in syntactic transitivity or not. In other terms, is a null-A construction, read as anticausative or 
passive depending on the context, syntactically transitive (V\{(A), P $\})$ or intransitive $(\mathrm{V}\{\mathrm{S}\})$ ?

Without explicitly raising the question, Creissels brought it down to that of the operation level of syntactic transitivity, which can be considered to receive an answer in the two following statements combined:

In languages that have radical alignment, the transitive and intransitive predications can be described as instances of a single predicative construction including an obligatory morphosyntactic slot shared by $\mathrm{S}$ and one of the core terms of the transitive predication (either A or P), and an optional morphosyntactic slot whose instantiation depends on the transitivity properties of the verb, for the other core term of the transitive predication. [Creissels 2014: 926]

In languages with radical P-alignment, the existence of a distinction between intransitive predications and transitive predications with a null-A is ensured only if there are transitive verbs with which, either an NP in A role is obligatorily present, or the absence of an NP in A role, if not licensed by a detransitivizing derivation, obligatorily triggers an anaphoric reading. [Ibid.: 930]

In languages with radical P-alignment, but a restricted use of null agents, a distinction between transitive and intransitive predications exists, but lies entirely in the transitivity properties of the verb: if the argument structure of the verb implies an agent, the A slot has to be instantiated, whereas if it does not, the A slot remains empty. In languages which combine P-radical alignment with an "unrestricted use of an arbitrary reading of null A's” [Creissels 2014: 924], though, the A slot is not instantiated every time a verb implies the participation of an agent, since underlyingly present, but pragmatically demoted agents are unrealized.

Considering that unrestricted weak lability blurs any distinction between intransitive and transitive predications, even a formal one (which exists in languages with non-radical alignment), and supported by his analysis of the lability tests applied to Godoberi and Bagvalal, Creissels concluded that the absence of a formal distinction may equal an absence of syntactic distinction. In other words, the only existing distinction between transitive and intransitive predications lies in the realization of the A term: syntactic transitivity operates not on the 
predicative constructions, since there is only one construction formally and syntactically, but on their realizations ${ }^{16}$. The systematic application of four lability tests to Andi verbs substantiates this assumption.

Further evidence might be provided by an analysis of the syntactic status of passive lability in Andi. If syntactic transitivity does operate at realizations level, argument structure preserving P-lability has to involve a change in syntactic transitivity in the same way as argument structure modifying P-lability does, and one should be able to prove it through lability tests. Nevertheless, this task appears to be more complex than for anticausative lability. The only test I have thought of so far is that of the imperative form. The use of intransitive imperatives in the context of an unspecified agent represented by an empty A slot would corroborate our claim, whereas that of transitive imperatives would rather challenge it.

However, the elicitation of imperatives in that context proved to be difficult for two reasons, and might even be inadequate. On the one hand, the imperative of semantically satisfactory sentences such as 'My son, be praised', 'My daughter, be rewarded' or 'My friend, be blessed' is rendered in Andi by complex sentences using a main intransitive clause and a circumstantial subordinate clause (cf. (50)).

(50) Stimulus: 'Boy, be praised'

wofo, fu-w $x^{w} a d-u-m \quad$ adam-di

boy[M] good-M behave-PST-IMP(ITR) people-ERG

w-ets:iq $\chi$-ijal-?a!

M-praise-PTCP:NPST.OBL-SUPER

'Boy, behave yourself so as to be praised (lit.: behave yourself well on being praised by people)'.

On the other hand, semantically dubious sentences where the agentivity properties of the imperative subject are not consistent with the use of a passive imperative, such as 'Door, be closed', if ever

16 This hypothesis necessitates that cases of unexpressed agents which are retrievable by context (as in Russian Misha razbil chashku togda zhe, kogda razbil tarelku 'Misha broke the cup at the same time as $\varnothing$ broke the plate'), which are common in Andi, be excluded from cases of 'unrealized' agents. This is possible if we consider that, if retrievable by context (and hence not arbitrary), an agent does instantiate the A slot, be it formally absent in the sentence. 
allowed by any speakers, should be interpreted by them as instances of anticausative, rather than passive situations ('door, close yourself!'), because a door cannot do anything so as to be closed by someone, which neutralizes the test's applicability. It is therefore necessary to add an NP representing the agent. I tried to elicit such sentences with one consultant. He translated 'Door, be closed by the child!' by a causative (transitive) imperative form in a sentence meaning 'Door, make the child close you' (cf. (51)).

(51) Stimulus: 'Door, be closed by the child!'

$\begin{array}{ll}\text { hints': } u, & \text { motf'if: } u-<r>o \\ \text { door[INAN } & \text { child.OBL:M-AFF }<\text { INAN }_{2}> \\ \text { men=gu } & r \text {-ifd-oll-o! } \\ \text { thou[NOM]=EMPH } & \text { INAN }_{2} \text {-close-CAUS-IMP(TR) } \\ \text { 'Door, make the child close you!' }\end{array}$

The least unsuitable candidates for elicitation would be situations which cannot even be interpreted as anticausative, like 'Floor, be swept!', because the spontaneous event reading is unavailable due to the semantic properties of the verb ("'Floor, sweep yourself!'), which require the involvement of an agentive participant. These kinds of sentences might therefore be read as involving an unexpressed agent and translated through an imperative, in the absence of any relatable semantic context. If ever possible, an occurrence of intransitive imperatives with a passive meaning would all the more support the present assumption if elicited in combination with an ergative NP expressing a demoted agent. Indeed, the presence of a demoted ergative agent in combination with an intransitive imperative with a nominative addressee would evince that such a construction has a passive meaning. However, the elicitation of such nonsensical sentences is doubtfully possible with hardly any speaker. So far, my only attempt to elicit such a sentence was unsuccessful. Indeed, the speaker translated 'Saucepan, be washed!' by an intransitive (inchoative) verb in a sentence which was retranslated as 'Saucepan, wash yourself!', i.e. an anticausative event (cf. (52)).

(52) Stimulus: 'Saucepan, be washed!'

$\begin{array}{ll}\chi \text { agi, } & \text { men }=g u \\ \text { saucepan[INAN2] } & \text { thou[NOM] }=\mathrm{EMPH}\end{array}$


r-erts':omi-t-i-b!

INAN2-clean-INCH-PST-IMP(ITR)

'Saucepan, wash yourself (lit.: become clean)!'

Besides, even if such sentences were translatable through transitive imperatives, this would not be a reliable result because of their absurdity.

Above all, the imperative test could simply be inadequate because of its probable strictly semantic nature. Indeed, if verbs can be incompatible with the intransitive imperative pattern solely because they cannot express a spontaneous event (which is the present claim), it means that this pattern cannot be used but in an anticausative sense. Therefore, the incompatibility of the intransitive imperative pattern with a passive interpretation is not only probable (otherwise we would expect its compatibility with factitive and causative verbs), but could also not be apt to invalidate Creissels's hypothesis.

Testing null-A constructions with a passive interpretation therefore appears to be a difficult, not to say impossible task. However, the difficulty of testing passive-like contexts independently from their anticausative counterparts shows how much they are intertwined in the semantics of null-A constructions when not restricted by morphological features overtly signaling the presence of a semantic agent.

\section{Summary}

In this analysis of lability in Andi, two issues were discussed: (i) Which are the Andi labile verbs and by which methods were they identified? (ii) What is the specificity of Andi lability and what conclusions can be drawn about transitivity in Andi?

In order to identify and study Andi labile verbs, one has to make a difference between anticausative and passive lability, the former being "more labile" than the latter. It is also necessary to take into account three typological features: radical P-alignment, the absence of agent demoting or removing morphology, and the absence of restrictions on arbitrary readings of null-A constructions. Indeed, in such a context, all transitive verbs are subject to passive lability, and cases of anticausative lability are always ambiguous with passive lability. The tests designed to disambiguate anticausative from passive uses of null-A transitive verbs show that all primary transitive verbs 
lend themselves to both passive and anticausative lability. This result allows to conclude that there is probably no syntactic difference between passive and anticausative lability in Andi, both involving a change in syntactic transitivity. This finding corroborates Creissels's theory that in languages sharing with Andi the relevant typological features, transitivity operates not at the level of predicative constructions, but at the level of their realizations. Testing cases of passive lability for intransitivity might help to provide further evidence, but this task is more complex than the testing of anticausative lability.

\section{Abbreviations}

ABS - absolutive (Adyghe); AFF — affective case; AN — animate gender; AOR - aorist; CAUS - causative derivation; CL — gender (class) marker; CMP - completive (Mandinka); CONT — contlocative case; CVB converb; DEF - definite (Mandinka); DEM - demonstrative; DYN - dynamicity (Adyghe); EL — elative; EMPH — emphatic particle; ERG - ergative case; ESS — essive; F — feminine gender; FCT — factitive derivation; FUT — future; GEN - genitive case; GEN1 - genitive case 1 (Hinuq); HAB habitual; IMP(ITR) - intransitive imperative; IMP(TR) - transitive imperative; IN — illocative case (Hinuq); INAN1 — first inanimate gender; INAN2 second inanimate gender; INCH — inchoative derivation; INTR — intransitive; LAT — lative; $\mathrm{M}$ - masculine gender; NEG — negation; NOM — nominative case; OBL — oblique; PF — perfect; POS — positive (Mandinka); POSS — alienable possession (Adyghe); PR — posessor (Adyghe); PROG — progressive; PRS — present (Hinuq); PST — past stem; PTCP:NPST — non-past participle; RFL — reflexive; SUPER — superessive case; TR — transitive.

\section{References}

Aglarov 2002 - M. A. Aglarov. Andiytsy: Istoriko-etnograficheskoye issledovaniye [The Andi People: A Historico-Ethnographic Study]. Makhachkala: Yupiter, 2002.

Arkadyev et al. 2009 - P. M. Arkadyev, Yu. A. Lander, A. B. Letuchiy, N. R. Sumbatova, Ya. G. Testelets. Osnovnyye svedeniya ob adygeyskom yazyke [General information about the Adyghe language]. Ya. G. Testelets (ed.). Aspekty polisintetizma: ocherki po grammatike adygeyskogo yazyka [Aspects of Polysynthetism: A Grammar Sketch of the Adyghe Language]. Moscow: Russian State University for the Humanities, 2009. P. 17-120.

Creissels 2014 - D. Creissels. P-lability and radical P-alignment. Linguistics. 2015. Vol. 52. Iss. 4. P. 911-944. 
Creissels 2015 - D. Creissels. Valency properties of Mandinka verbs. A. Malchukov, B. Comrie (eds.). Valency Classes in the World's Languages. Berlin; Boston: De Gruyter Mouton, 2015. Vol. 1. P. 221-260.

Dirr 1906 - A. M. Dirr. Kratkiy grammaticheskiy ocherk andiyskago yazyka [Brief Grammar Sketch of the Andi Language]. (Sbornik materialov dlya opisaniya mestnostey i plemen Kavkaza 32). Tiflis: Upravleniye Kavkazskogo uchebnogo okruga, 1906.

Dixon 1994 — R. M. W. Dixon. Ergativity. Cambridge: Cambridge University Press, 1994.

Forker 2013 — D. Forker. A Grammar of Hinuq. Berlin; Boston: De Gruyter Mouton, 2013.

Haspelmath 1987 - M. Haspelmath. Transitivity Alternations of the Anticausative Type. (Abteilung Allgemeine Sprachwissenschaft: Arbeitspapier 5). Köln: Institut für Linguistik, Universität zu Köln, 1987.

Haspelmath 1993a - M. Haspelmath. More on the typology of inchoative / causative verb alternations. B. Comrie, M. Polinsky (eds.). Causatives and Transitivity. (Studies in Language Companion Series 23). Amsterdam; Philadelphia: John Benjamins Publishing Company, 1993. P. 87-121.

Haspelmath 1993b - M. Haspelmath. A Grammar of Lezgian. Berlin; Boston: De Gruyter Mouton, 1993.

Kibrik 1996 - A. A. Kibrik. Transitivity in lexicon and grammar. A. E. Kibrik, S. G. Tatevosov, A. Eulenberg (eds.). Godoberi. Munich: Lincom Europa, 1996. Vol. 2. P. 107-142.

Letuchiy 2009a - A. B. Letuchiy. Towards a typology of labile verbs: Lability vs. derivation. P. Epps, A. Arkhipov (eds.). New Challenges in Typology: Transcending the Borders and Refining the Distinctions. Berlin; Boston: De Gruyter Mouton, 2009a. P. 247-268.

Letuchiy 2009b - A. B. Letuchiy. Kauzativ, dekauzativ i labilnost [Causative, anticausative and lability]. Ya. G. Testelets (ed.). Aspekty polisintetizma: Ocherki po grammatike adygeyskogo jazyka [Aspects of Polysynthetism: A Grammar Sketch of the Adyghe Language]. Moscow: Russian State University for the Humanities, 2009b. P. 372-428.

Letuchiy 2010 - A. Letuchiy. Lability and spontaneity. P. Brandt, M. Garcia García (eds.). Transitivity: Form, Meaning, Acquisition, and Processing. Amsterdam: John Benjamins, 2010. P. 237-255.

Letuchiy 2013 - A. B. Letuchiy. Tipologiya labilnykh glagolov [Typology of Labile Verbs]. Moscow: Yazyki slavyanskoy kultury, 2013.

Lyutikova 2001 - E. A. Lyutikova. Labilnyye glagoly [Labile verbs]. A. A. Kibrik, S. G. Tatevosov, E. A. Lyutikova, K. I. Kazenin (eds.). Bagvalinskiy yazyk: Grammatika. Teksty. Slovari [The Bagvalal 
Language: Grammar. Texts. Lexicons]. Moscow: A. M. Gorky Institute of World Literature RAS; Naslediye, 2001. P. 377-383. Rasprostranennost vladeniya yazykami po subektam Rossiyskoy Federatsii

[Rate of spoken languages by constituent entities of the Russian Federation]. Russian Federal State Statistics Service, 2002. Available at: http://www.perepis2002.ru/index.html?id=78 (accessed on 25.12.2019)

Salimov 1968 - Kh. S. Salimov. Gagatlinskiy govor andiyskogo yazyka [The Gagatl Dialect of the Andi Language]. PhD Thesis. G. Tsadasa Institute of Language, Literature and Art of Dagestan Scientific Centre RAS, Makhachkala, 1968.

Suleymanov 1957 - Ya. G. Suleymanov. Grammaticheskiy ocherk andiyskogo yazyka (po dannym govora s. Rikvani) [A Grammar Sketch of Andi (Rikwani Dialect)]. Moscow: Institute of Linguistics AS USSR, 1957.

Tsertsvadze 1965 - I. I. Tsertsvadze. Andiuri ena [The Andi Language]. Tbilisi: Metsniereba, 1965. 